\title{
The Role of Positive Emotions to Increase the Effect of Store Atmosphere and Discount on Impulse Buying
}

\author{
I. Komang Setiawan and I. Gusti Agung Ketut Sri Ardani
}

\section{ABSTRACT}

\begin{abstract}
This study aims to analyze the effect of store atmosphere and price discounts on impulse buying with positive emotions as a mediator for consumers at Coco Mart in Denpasar with 85 respondents. Data was collected by distributing questionnaires, then the data was processed using path analysis with the help of SPSS software. Based on the results, the store atmosphere has a positive and significant effect on impulse buying. Store Atmosphere has a positive and significant effect on positive emotions. Price discount has a positive and significant effect on impulse buying. Price discount has a positive and significant effect on positive emotions. Positive emotions have a positive and significant impact on impulse buying. Positive emotions can mediate the effect of store atmosphere and price discounts on impulse buying.
\end{abstract}

Keywords: impulse buying, price discount, positive emotion, store atmosphere.

\author{
Submitted : December 30, 2021 \\ Published : February 13, 2022 \\ ISSN: $2507-1076$ \\ DOI: $10.24018 / \mathrm{ejbmr} .2022 .7 .1 .1236$ \\ I. Komang Setiawan \\ Faculty of Economy and Business, \\ Udayana University, Bali, Indonesia. \\ I. Gusti Agung Ketut Sri Ardani \\ Faculty of Economy and Business, \\ Udayana University, Bali, Indonesia. \\ (e-mail: setiawanejbmr@gmail.com)
}

*Corresponding Author

\section{INTRODUCTION}

In the current era of globalization, people's consumption patterns continue to change with an increase in income which causes an increase in people's needs. This has triggered the rapid development of retail businesses in Indonesia (Negara, 2018). Supported by government policies that continue to encourage the progress of the retail business, the opportunity for this business is very large. As a result, the retail industry is experiencing very tight competition. The growth of the retail business in Indonesia continues to increase every year and is expected to continue to grow in the next few years (Sudarsono, 2017).

One form of retail business is a 'convenience store'. Convenience store is retail outlets with a modern concept that sell daily necessities which are located around residential areas so that they are easily accessible and can compete with retail outlets that are still traditional (Singh et al., 2020). One of the retails that is experiencing rapid development in Bali is Coco Mart. Coco Mart offers a one-stop shopping experience by combining a grocery store with fresh produce, a bakery, a grocery store, and dairy products among household goods. Coco Mart was first opened in 2006 and now has 42 outlets spread across Badung, Denpasar, Gianyar, and Tabanan.

To increase the sales turnover of Coco Mart, a marketing strategy must be carried out and also improve the quality of service. The availability of complete products with comfortable services will make consumers happy and will encourage consumers to shop to increase store sales turnover. This sales turnover is obtained through purchasing activities made by consumers from stores.

One of the activities carried out is impulse buying or unplanned purchases. Impulse buying is very important in business through survey results which show that an average of $65 \%$ of consumers sometimes always buy something without prior planning, while the number of consumers who make purchases based on their wishes is $15 \%$ (Temaja et al., 2015).

Impulse buying occurs when a customer has an unexpected experience of buying something without delay and without additional evaluation in fulfilling the desire. Consumers buy products not only because of need but also because of a sudden urge to buy (Ünsalan, 2016). Relatively very few consumers can control their impulse buying, impulse buying is usually accompanied by excitement, pleasure, and a strong urge to buy (Parsad et al., 2017). There is evidence of a pleasant psychological state and there is also an element of pleasure in it when doing impulse buying (Gumilang \& Nurcahya, 2016). Impulse buying is a type of purchase that dominates the retail market today. The proportion of impulse buying in retail businesses reaches 80 percent (Choudhary, 2014).

One of the factors that can trigger impulse buying is the store atmosphere. Store atmosphere needs to be considered by retail marketers, especially convenience store because a good store atmosphere setting will make consumers feel comfortable and feel at home for long in the store so that it can increase the potential of consumers to shop more (Hussain \& Siddiqui, 2019). The atmosphere and perception of the atmosphere both outside and inside the store can provide a shopping experience that is difficult for consumers to forget, even the atmosphere of the store can affect the feelings, behavior of consumers to make impulse purchases and cause consumers to feel more comfortable to stay longer in the store

Retail businesses use lighting, colors, music, and scents to stimulate customer perceptions and emotional responses and ultimately influence buying behavior (Widyastuti, 2018). 
Consumers who are in the store for a long time will be able to increase the potential for unplanned purchases they make. Dewi \& Giantari (2015) stated that the store atmosphere needs to be considered by marketers because a good atmosphere setting can touch the emotions of consumers to shop more.

In addition to store atmosphere, another factor that influences consumer impulse buying is price discount. It is widely known that price discounts are the most powerful element to influence consumer impulse buying, both in traditional and modern markets (Handayani et al., 2019). Price discount is one of the sales promotion strategies by offering products at lower prices than they should (Gumilang \& Nurcahya, 2016). According to Lee \& Chen-Yu (2018) stated that price discounts are the most widely used marketing strategy both online and offline. By offering products at lower prices than they should be, it will attract consumers to shop more.

When consumers are interested in entering and visiting stores, management is required to be able to process consumer emotions into positive emotions. Positive emotions are one of the factors that influence consumers in impulse buying, where consumers are feeling happy and excited (Alfarizi et al., 2017). Emotionally positive responses to the shop surroundings could be capable of having an effect on unexpected purchases. Emotion is an impact of feeling that is a crucial issue for customers in buying decisions. The feeling or emotion issue is a transient assemble as it pertains to a selected scenario or object (Hetharie et al., 2019)

\section{LITERATURE REVIEW}

\section{A. Store Atmosphere}

The store atmosphere is defined as an effort to design a store environment to create certain emotional effects on shoppers that increase purchase opportunities (Akram et al., 2016). To create the right store atmosphere, management may adopt a lighting scheme that discourages shoppers from inspecting the store products, causing negative effects. Inadequate lighting levels reduce the visual perception needed to complete the store atmosphere (Saad \& Metawie, 2015). Therefore, proper lighting is very necessary for creating a comfortable store atmosphere for consumers, because products that are under proper lighting have an impact on consumers to make unplanned purchases.

\section{B. Price Discount}

According to Kotler \& Amstrong (2008:127), "price discount is the savings offered to consumers from the normal price of a product, which is listed on the label or packaging of the product which Discounting is a pricing strategy that involves a long-term plan to systematically lower prices after introducing a high-priced product."

\section{Positive Emotions}

Positive emotions are factors that can affect impulse buying, when consumers shop, where consumers experience feelings of pleasure and joy. The existence of this positive emotion results in a sudden desire. When positive consumer emotions increase, this will also increase impulse buying made by consumers (Kurniawan \& Kunto, 2013).

\section{Impulse Buying}

Impulse buying is a behavior carried out by a consumer without being planned and carried out spontaneously (Ruswanti, 2016). Unplanned buying behavior is a buying behavior made in the store, where the purchases made are different from those previously planned by consumers. The same thing was also expressed by Putra \& Sukawati (2015) that "impulse buying is an unplanned purchase or sudden purchase activity without any prior planning when entering the store. Impulsive buying is shopping behavior that occurs unplanned, emotionally interested, where the process and decision-making are carried out quickly without thinking about all available information and alternatives."

\section{E. Hypothesis}

Kurniawan \& Kunto (2013), show that store atmosphere has a positive and significant influence on impulse buying. This states that the better the store atmosphere applied by the company, the higher the impulse buying from consumers at the company concerned.

\section{H1: Store Atmosphere has a positive and significant effect on Impulse buying}

Gumilang \& Nurcahya (2016), Melina \& Kadafi (2017) state that price discounts have a positive and significant effect on impulse buying. This research is also supported by Suhiryanto et al. (2018) who also states that price discounts have a positive and significant influence on impulse buying.

\section{H2: "Price discount has a positive and significant effect on Impulse Buying"}

Alfarizi et al. (2017) showed that store atmosphere had a positive and significant effect on positive emotions. This research is also supported by Maulana (2018) who also states that store atmosphere has a positive and significant influence on positive emotions. According to Banu Saputro (2019), the store atmosphere has a positive and significant influence on impulse buying.

\section{H3: "Store Atmosphere has a positive and significant effect on Positive Emotions"}

\section{F. Price Discount on Positive Emotions}

Gumilang \& Nurcahya (2016), "price discount has a positive effect on positive emotions." Kurniawan \& Kunto (2013), "there is a positive and significant effect of promotion on positive emotions. This is also supported by Putra \& Sukawati (2015) who state that the price discount has a positive and significant effect on positive emotions."

\section{H4: "Price discount has a positive and significant effect on positive emotions"}

Amiri et al. (2012), "the more positive emotions at the time of purchase can lead to an increase in impulsive purchases, positive emotions play an important role in their intention to buy." Permatasari et al. (2017) state, "the emotional state of consumers plays an important role in deciding to make an impulsive purchase." 
H5: "Positive Emotions have a positive and significant effect on Impulse Buying",

Gunawan Kwan (2016) states, "store atmosphere has a positive effect on Impulse Buying mediated by positive emotions." Dewi \& Giantari (2015), "store atmosphere has a positive and significant influence on impulse buying mediated by positive emotions." Hetharie et al. (2019) mentions, "store atmosphere has a positive and significant effect on impulse buying which is mediated by positive emotions."

H6: "Store atmosphere has a positive and significant effect on Impulse Buying mediated by positive emotions"

According to Banu Saputro (2019), "the price discount has a positive effect on Impulse Buying which is influenced by positive emotions." Rosyida et al. (2016), Diah Rani \& Purnami (2019) states that giving discounts to consumers with positive emotions is the variable that drives it.

H7: "Price discount has a positive and significant effect on impulse buying mediated by positive emotions."

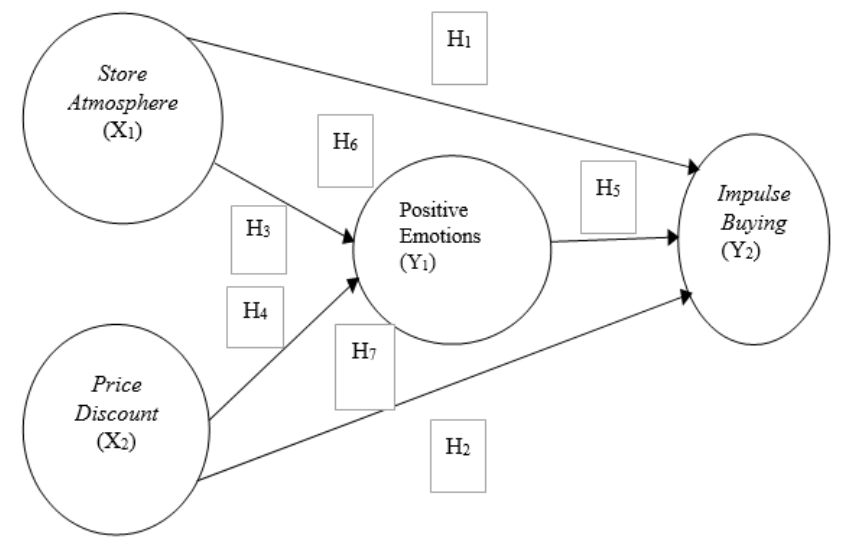

Fig. 1. Conceptual Framework.

\section{METHODOLOGY}

This research uses an associative approach. The subjects are CocoMart's consumers in Denpasar, who had at least purchased in the last 1 month.

The indicators for measuring store atmosphere according to Gumilang \& Nurcahya (2016) are: 1) Lighting; 2) Music; 3) Air regulation; 4) Layout; 5) Room's Smell.

According to Melina \& Kadafi (2017) indicators to measure price discount are 1) Regularly giving price discounts; 2) Providing attractive discounts/rebates; 3) Giving discounts with quite a lot of quantity

Indicators for positive emotion variables in this study are: 1) Feeling happy; 2) Feeling satisfied; 3) Feel comfortable; 4) Feeling driven; 5) Feeling excited

The indicators used to measure the impulse buying variable according to Gumilang \& Nurcahya (2016) are 1) Unplanned purchases; 2) Purchases made by customers without thinking about the consequences of the purchase; 3 ) Purchases are influenced by emotional states; 4) Purchases are influenced by attractive offers

In this study, the method of determining the sample used is purposive sampling, namely the determination of the sample with certain considerations. The ideal sample size is 5-10 times the number of indicators. According to the reference, the sample is 85 respondents. Data collection in this study was carried out using a questionnaire. Questionnaires were given directly to respondents to respondents who had shopped at Coco Mart Denpasar. Respondent's answers were measured using a Likert scale with a scale of 1 to 5 . In this study, the analytical technique used was path analysis.

\section{RESUlTS AND DISCUSSION}

\section{A. Characteristics of Respondents}

TABLE I: CHARACTERISTICS OF RESPONDENTS

\begin{tabular}{ccc}
\hline Variables & Classification & Total (Person) \\
\hline \multirow{2}{*}{ Gender } & Man & 36 \\
& Woman & 49 \\
\hline \multirow{3}{*}{ Age } & Total & 85 \\
& 17-21 years old & 12 \\
& 22-26 years old & 46 \\
& 27-32 years old & 19 \\
Educational & 33-38 years old & 85 \\
Background & Total & 24 \\
& High School & 21 \\
& Diploma & 34 \\
& Bachelor's Degree & 6 \\
\hline \multirow{3}{*}{ Job Status } & Master's Degree & 85 \\
& Total & 26 \\
& Student & 33 \\
& Private employees & 10 \\
& entrepreneur & 12 \\
\hline
\end{tabular}

B. Instrument Test

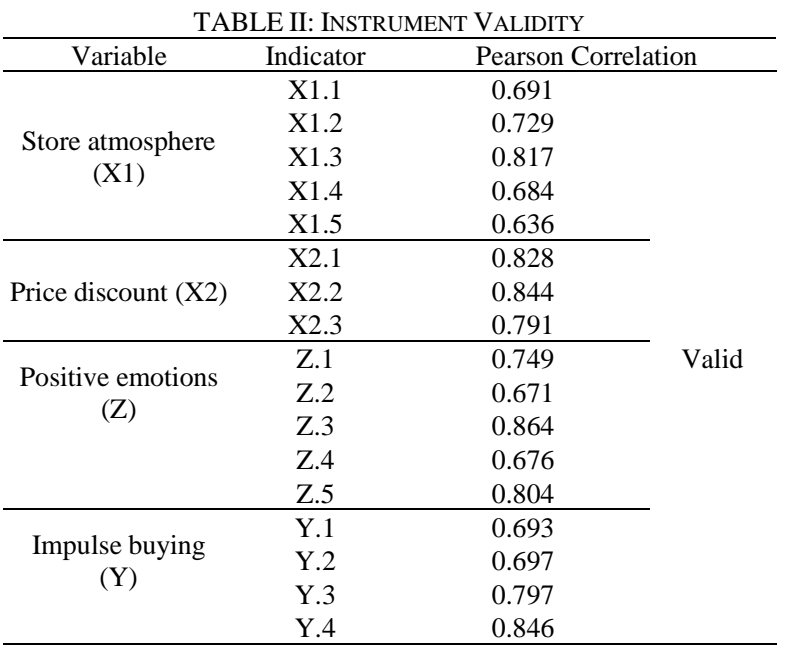

\begin{tabular}{ccc}
\multicolumn{3}{c}{ TABLE III: RELIABILITY TEST RESULTS } \\
\hline Variabel & \multicolumn{1}{c}{ Cronbach Alpha } \\
\hline X1 (Store atmosphere) & 0.755 & \\
X2 (Price discount) & 0.756 & Reliable \\
Z (Positive emotions) & 0.804 & \\
Y (Impulse buying) & 0.753 & \\
\hline
\end{tabular}

\section{Path Analysis}

\begin{tabular}{|c|c|c|c|c|c|c|}
\hline & \multicolumn{3}{|c|}{ UnstandardizedCoefficients } & $\begin{array}{l}\text { Standardized } \\
\text { Coefficients }\end{array}$ & \multirow{2}{*}{$\mathrm{t}$} & \multirow{2}{*}{ Sig. } \\
\hline & Model & $\mathrm{B}$ & Std. Error & Beta & & \\
\hline \multirow{4}{*}{1} & (Constant) & 5.711 & 2.407 & & 2.373 & 0.020 \\
\hline & Store atmosphere & 0.447 & 0.083 & 0.482 & 5.377 & 0.000 \\
\hline & Price discount & 0.489 & 0.084 & 0.284 & 3.170 & 0.002 \\
\hline & R square: 0.358 & \multicolumn{2}{|c|}{ Sig.F: 0.000} & Dependent: & ositive & notions \\
\hline
\end{tabular}


TABLE V: PATH COEFFICIENT II

\begin{tabular}{ccccccc}
\hline \multicolumn{8}{c}{ UnstandardizedCoefficients } & \multicolumn{3}{c}{$\begin{array}{c}\text { Standardized } \\
\text { Coefficients }\end{array}$} & t & Sig. \\
\cline { 1 - 5 } Model & B & Std. Error & Beta & & \\
\hline (Constant) & 1.540 & 1.180 & & 1.305 & 0.196 \\
1 & Store atmosphere & 0.171 & 0.066 & 0.226 & 2.584 & 0.012 \\
Price discount & 0.286 & 0.131 & 0.234 & 2.183 & 0.032 \\
& Positive emotions & 0.384 & 0.075 & 0.471 & 5.122 & 0.000 \\
& Sig.F: 0.000 & R square: 0.671 & Dependent: Impulse buying \\
\hline
\end{tabular}

\section{Direct Effects}

The effect of store atmosphere (X1) on Positive emotions $(\mathrm{Z})$ is 0.482 . The effect of price discount (X2) on Positive emotions $(\mathrm{Z})$ of 0.284 . The effect of store atmosphere (X1) on impulse buying (Y) is 0.226 . The effect of price discount (X2) on impulse buying (Y) is 0.234 . The effect of Positive emotions $(\mathrm{Z})$ on impulse buying $(\mathrm{Y})$ is 0.471 .

\section{E. Indirect Effects}

The effect of store atmosphere (X1) on impulse buying (Y) with Positive emotions $(\mathrm{Z})$ as a mediating variable of: $1 \times 5=$ $0.482 \times 0.471=0.227$. The effect of price discount $(\mathrm{X} 2)$ on impulse buying (Y) with Positive emotions $(\mathrm{Z})$ as a mediating variable of: $2 \times 5=0.284 \times 0.471=0.133$.

\section{F. Total Effects}

The total effect of the store atmosphere variable $(\mathrm{X} 1)$ on impulse buying $(\mathrm{Y})$ with Positive emotions $(\mathrm{Z})$ as a mediating variable: $3+(\beta 1 \times 5)=0.226+0.227=0.453$. The total effect of the price discount variable (X2) on impulse buying (Y) with Positive emotions $(\mathrm{Z})$ as a mediating variable: $4+$ $(\beta 2 \times 5)=0.234+0.133=0.367$

\section{G. The Effect of Store Atmosphere on Impulse Buying}

The effect of store atmosphere (X1) on impulse buying $(\mathrm{Y})$ is 0.226 with a sig.t value comparison of 0.012 which is less than the significant value used $(0.012<0.05)$, store atmosphere has a positive and significant effect on impulse buying. This means that the better and more attractive the atmosphere of the store, the more impulse buying consumers will be.

\section{H. The Effect of a Price Discount on Impulse Buying}

The effect of price discount (X2) on impulse buying (Y) is 0.234 with a comparison of sig.t value of 0.032 less than the significant value used $(0.032<0.05)$, price discount has a positive and significant effect on impulse buying. This means that the more often the company offers discounts, the more consumers will buy impulsively.

\section{The Effect of Store Atmosphere on Positive Emotions}

The effect of store atmosphere (X1) on Positive emotions (M) is 0.482 with a sig.t value comparison of 0.000 less than the significant value used $(0.000<0.05)$. This figure shows that the store atmosphere has a positive and significant effect on Positive emotions. This means that the better and more attractive the atmosphere of the store, the positive emotions felt by consumers will increase.

\section{J. The Effect of a Price Discount on Positive Emotions}

The effect of price discount (X2) on Positive emotions (M) is 0.284 with a sig.t value comparison of 0.002 less than the significant value used $(0.002<0.05)$. This figure shows that the price discount has a positive and significant effect on
Positive emotions. This means that the more often companies offer discounted prices, the Positive emotions felt by consumers will increase.

\section{$K$. The Effect of Positive Emotions on Impulse Buying}

The effect of Positive emotions (Z) on impulse buying (Y) is 0.471 with a sig.t value comparison of 0.000 which is less than the significant value used $(0.000<0.05)$, Positive emotions have a positive and significant effect on impulse buying. This means that the higher the level of Positive emotions felt by consumers when shopping, the higher their desire to make impulse purchases.

\section{Positive Emotions Mediate the Effect of Store Atmosphere on Impulse Buying}

Based on the results of the Sobel test, the results of the tabulation $\mathrm{Z}=4.234>1.96$, which means that the Positive emotions variable significantly mediates the relationship between store atmosphere and impulse buying. This means that the better and more attractive the atmosphere of the store, the Positive emotions felt by consumers will increase so that it will increase their desire to make impulse purchases.

\section{Positive Emotions Mediate the Effect of a Price Discount on Impulse Buying}

Based on the results of the Sobel test, it shows that the tabulation results $Z=2,948>1.96$, which means that the Positive emotions variable significantly mediates the relationship between price discount and impulse buying. This means that the more often companies offer discounted prices, the Positive emotions felt by consumers will increase so that it will increase their desire to make impulse purchases.

\section{N. Research Implication}

This research has been able to explain the theoretical model used as the basis for formulating the hypothesis, namely the role of Positive emotions in mediating the influence of store atmosphere and price discounts on impulse buying. The results of the theoretical model explain that the factors that influence impulse buying are the positive emotions felt by consumers through a good store atmosphere and price discounts offered by the company.

\section{O. Research Limitations}

The number of respondents is only 85 people and only discusses the consumer behavior of Coco Mart in Denpasar, so the results of this study cannot be generalized to other companies. There are still other variables that can affect impulse buying outside the model described in this study.

\section{CONCLUSION}

To increase consumer impulse buying, Coco Mart can make consumers feel positive emotions when shopping by ensuring consumers feel satisfied and comfortable when shopping at Coco Mart by maintaining good store cleanliness such as providing hand sanitizer and hand washing, so consumers feel comfortable and safe when shopping. Coco Mart can also offer discounts on a regular basis and increase the number of discounted products offered so that consumers will be interested in buying these products without prior planning. In addition, Coco Mart can also provide bonus 
packages for basic needs, such as buy 2 get one free for purchasing household materials, because as we know during this pandemic, people really need basic needs. To increase purchases, you can also hire famous influencers to shop, so that people can find out about Coco Mart through various social media platforms.

For future researchers, it is necessary to consider examining other variables, factors, and indicators outside of store atmosphere, price discounts and positive emotions to determine impulse buying. Such as lifestyle variables, hedonic motifs, and others.

\section{REFERENCES}

Akram, U., Hui, P., Khan, M. K., Hashim, M., \& Rasheed, S. (2016). Impact of Store Atmosphere on Impulse Buying Behaviour: Moderating Effect of Demographic Variables. International Journal of $U$ - and e-Service, $\begin{array}{lll}\text { Science } & \text { Technology, 9(7), 43-60 }\end{array}$ https://doi.org/https://doi.org/10.14257/ijunesst.2016.9.7.05.

Alfarizi, R. A., Rachma, N., \& Hufron, M. (2017). Pengaruh Promosi Penjualan Dan Atmosfer Toko Terhadap Pembelian Impulsif Dengan Emosi Positif Sebagai Variabel Intervening Pada Konsumen Superindo Tlogomas Malang. E - Jurnal Riset Manajemen Fakultas Ekonomi Unisma, 1(1), 75-87.

Amiri, F., Mohsen, S., \& Tohid, A. (2012). Evaluation of Effective Fashionism Involvement Factors on Impulse Buying Behavior of Costumers and Condition of Interelation Between These Factor. Journal of Basic And Applied Scientific Research, 2(9), 9413-9419.

Banu Saputro, I. (2019). Pengaruh Price Discount Dan Store Atmosphere Terhadap Impulse Buying Dengan Positive Emotion Sebagai Variabel. Jurnal Ilmu Manajemen, 16(1), 35-47.

Choudhary, S. (2014). Study of Impulse Buying Behavior of Consumers. International Journal of Advance Research in Computer Science and Management Studies, 2(9), 1-4

Dewi, K., \& Giantari, I. (2015). Peran Positive emotions Dalam Memediasi Store Atmosphere Terhadap Pembelian Impulsif (Studi Pada Konsumen Matahari Department Store Duta Plaza Denpasar). E-Jurnal Manajemen Universitas Udayana, 4(12), 241

Diah Rani, N. P. K., \& Purnami, N. M. (2019). Peran Shopping Emotion Dalam Memediasi Pengaruh Atmosfer Ritel Dan Promosi Terhadap Impulse Buying. E-Jurnal Manajemen Universitas Udayana, 8(6), 3873.

https://doi.org/https://doi.org/10.24843/ejmunud.2019.v08.i06.p21.

Gumilang, W. A., \& Nurcahya, I. K. (2016). Pengaruh Price Discount Dan Store Atmosphere Terhadap Emotional Shopping Dan Impulse Buying. E-Jurnal Manajemen Unud, 15(3), 1859-1888.

Gunawan Kwan, O. (2016). Pengaruh Sales Promotion Dan Store Atmosphere Terhadap Impulse Buying Dengan Positive Emotion Sebagai Variabel Intervening Pada Planet Sports Tunjungan Plaza Surabaya. Jurnal Manajemen Pemasaran, 10(1), 27-34. https://doi.org/10.9744/pemasaran.10.1.27-34.

Handayani, W., Iryanti, E., Safeyah, M., \& Hardjanti, S. (2019). Improving traditional market sustainability in the industrial 4.0 era through impulsive buying strategy: A case in East Java, Indonesia. International Journal of Supply Chain Management, 8(3), 1045-1056.

Hetharie, J. A., Surachman, Hussein, A. S., \& Puspaningrum, A. (2019). SOR (Stimulus-organism-response) model application in observing the influence of impulsive buying on consumer"s post-purchase regret. International Journal of Scientific and Technology Research, 8(11), 2829-2841.

Hussain, S., \& Siddiqui, D. A. (2019). The Influence of Impulsive Personality Traits and Store Environment on Impulse Buying of Consumer in Karachi. International Journal of Business Administration, $10(3)$, https://doi.org/https://doi.org/10.5430/ijba.v10n3p50.

Kotler, P., \& Amstrong, G. (2008). Prinsip-Prinsip Pemasaran (12th ed.). Erlangga: Jakarta.

Kurniawan, D., \& Kunto, S. Y. (2013). Pengaruh Promosi Dan Store Atmosphere Terhadap Impulse Buying Dengan Shopping Emotion Sebagai Variabel Intervening Studi Kasus Di Matahari Department Store Cabang Supermall Surabaya. Jurnal Manajemen Pemasaran Petra, Universitas Kristen Petra, 1(2), 3.

Lee, J. E., \& Chen-Yu, J. H. (2018). Effects of price discount on consumers' perceptions of savings, quality, and value for apparel products: mediating effect of price discount affect. Fashion and Textiles, 5(1), 1. https://doi.org/10.1186/s40691-018-0128-2.

Maulana, R. I. (2018). Promosi dan Store Atmosphere Terhadap Shopping Emotion dan Impulse Buying. Jurnal Ecodemica, 2(2), 1.

Melina, \& Kadafi, M. A. (2017). Pengaruh price discount dan in-store display terhadap impulse buying. Forum Ekonomi, 19(2), 201-209.

Negara, A. A. B. J. (2018). Pengaruh Atmosfer Ritel dan Promosi yang Dimediasi Positive emotions. E-Jurnal Manajemen Unud, 7(7), 39443973.

Parsad, C., Prashar, S., \& Tata, V. S. (2017). Understanding nature of store ambiance and individual impulse buying tendency on impulsive purchasing behaviour: An emerging market perspective. Decision, 44(4), 297-311. https://doi.org/https://doi.org/10.1007/s40622-0170168-2.

Permatasari, I., Arifin, Z., \& Sunarti, S. (2017). Pengaruh Hedonic Consumption Dan Mediator Positive Emotions Terhadap Pembelian Impulsif (Survei Pada Pembeli Produk Fashion Di Malang Town Square Kota Malang). Jurnal Administrasi Bisnis S1 Universitas Brawijaya, 43(2), 1-9.

Putra, A., \& Sukawati, T. (2015). Peran Emotional Response Konsumen Dalam Memediasi Pengaruh Store Environment Terhadap Impulse Buying (Survei Pembeli Di Carrefour Kota Denpasar). E-Jurnal Manajemen Universitas Udayana, 4(1), 241.

Rosyida, S., Anjarwati, \& Lestari, A. (2016). Pengaruh Store Atmosfer Dan Promosi Penjualan. Journal of Research in Economics and Management, 16(1), 105-127.

Ruswanti, E. (2016). The Impact Of The Impulse Buying Dimension And Cherry Picking: An Empirical Study (Consumers Case Study in a mall in Central Jakarta). Journal of Indonesian Economy and Business, 31(1), 81. https://doi.org/https://doi.org/10.22146/jieb.10321.

Saad, M., \& Metawie, M. (2015). Store Environment, Personality Factors and Impulse Buying Behavior in Egypt: The Mediating Roles of Shop Enjoyment and Impulse Buying Tendencies. Journal of Business and $\begin{array}{lll}\text { Management } & \text { Sciences, } & \text { 69-77. }\end{array}$ https://doi.org/https://doi.org/10.12691/jbms-3-2-3.

Singh, J., Tyagi, P., Kumar, G., \& Agrawal, S. (2020). Convenience store locations prioritization: a fuzzy TOPSIS-GRA hybrid approach. Modern Supply Chain Research and Applications, 2(4), 281-302. https://doi.org/https://doi.org/10.1108/MSCRA-01-2020-0001.

Sudarsono, J. G. (2017). Pengaruh Visual Merchandising Terhadap Impulse Buying Melalui Positive Emotion Pada Zara Surabaya. Jurnal Manajemen Pemasaran, 11(1), 16-25. https://doi.org/https://doi.org/10.9744/pemasaran.11.1.16-25.

Suhiryanto, Arifin, R., \& Slamet, R. . (2018). Pengaruh Shoping LifeStyle, Discount dan Fashion Involvement terhadap Impulse Buying pada Mahasiswa Pengunjung Matos. E-Journal Riset Manajemen Prodi Manajemen Fakultas Ekonomi Unisa, 1(1), 57-66.

Temaja, I., Rahanatha, G., \& Yasa, N. (2015). Pengaruh Fashion Involvement, Atmosfer Toko Dan Promosi Penjualan Terhadap Impulse Buying Pada Matahari Department Store Di Kota Denpasar. E-Jurnal Manajemen Universitas Udayana, 4(6), 243.

Ünsalan, M. (2016). Stimulating Factors of Impulse Buying Behavior. Gazi Üniversitesi İktisadi ve İdari Bilimler Fakültesi Dergisi, 2(1), 572-593.

Widyastuti, P. (2018). Does visual merchandising, store atmosphere and private label product influence impulse buying? Evidence in Jakarta. Journal of Business and Retail Management Research, 12(3), 140-148. https://doi.org/https://doi.org/10.24052/jbrmr/v12is03/art-12. 